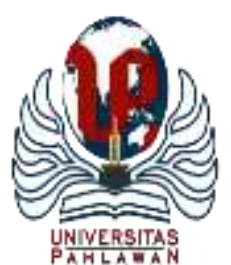

Edukatif : Jurnal Ilmu Pendidikan Volume 4 Nomor 1 Tahun 2022 Halm 836 - 843

EDUKATIF: JURNAL ILMU PENDIDIKAN

Research \& Learning in Education

https://edukatif.org/index.php/edukatif/index

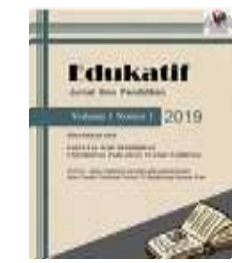

\title{
Analisis Framing Berita Pengevakuasian Korban Tanah Longsor di Sulut pada Media Online Sindonews.Com dan Kompas.Com
}

\author{
Thari Putri Kinanti Ishak ${ }^{1 凶}$, Hendra Setiawan ${ }^{2}$ \\ Universitas Singaperbangsa Karawang, Indonesia ${ }^{1,2}$

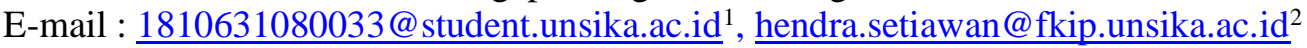

\begin{abstract}
Abstrak
Penelitian ini bertujuan untuk mengetahui bagaimana pemberitaan mengenai Pengevakuasian 9 Orang Penambang Emas Sulawesi Utara yang Tertimbun Longsor dan sedang hangat dibicarakan oleh dua media online, yaitu Sindonews.com dan Kompas.com. Metode penelitian yang digunakan adalah metode kualitatif. Hasil penelitian ini terdapat perbedaan pada bagian kutipan pernyataan dari sumber, dan terdapat persamaan pada bagian isi berita yang diawali dengan lead. Pada pemberitaan di media Kompas.com cenderung lebih banyak menggunakan kutipan dibandingkan dengan Sindonews.com.Pada struktur Skrip, 5W dalam ke dua media Kompas.com dan Sindonews.com sudah memenuhi, tetapi untuk How tidak terlalu dijelaskan dalam isi berita.media Kompas.com juga menjelaskan secara detail tentang jumlah korban dan kedalaman saat terjadinya longsor juga tindakan apa yang selanjutkan dilakukan setelah longsor ini terjadi.Sedangkan Sindonews.com hanya menjelaskan sekilas saja. Penggunaan bahan ajar berupa LKS dan buku paket SMP Kelas VIII mengenai teks berita dapat memudahkan siswa dalam memahami materi agar lebih efektif.
\end{abstract}

Kata Kunci: Analisis framing, media online.

\begin{abstract}
This study aims to find out how the news regarding the evacuation of 9 North Sulawesi Gold Miners who were buried by a landslide is currently being discussed by two online media, namely Sindonews.com and Kompas.com. The research method used is a qualitative method. The results of this study there are differences in the quote from the source, and there are similarities in the content of the news that begins with the lead. In the news on Kompas.com media, they tend to use quotes more than Sindonews.com. In the script structure, $5 \mathrm{~W}$ in both Kompas.com and Sindonews.com media has been fulfilled, but for How it is not explained much in the news content. Media Kompas.com also explained in detail about the number of victims and the depth at the time of the landslide as well as what actions to take after this landslide occurred. While Sindonews.com only briefly explained. The use of teaching materials in the form of worksheets and textbooks for Class VIII SMP regarding news texts can make it easier for students to understand the material more effectively.
\end{abstract}

Keywords:framing analysis, online media.

Copyright (c) 2022 Thari Putri Kinanti Ishak, Hendra Setiawan

$\checkmark$ Corresponding author

Email : 1810631080033@student.unsika.ac.id

DOI : https://doi.org/10.31004/edukatif.v4i1.1908

ISSN 2656-8063 (Media Cetak)

ISSN 2656-8071 (Media Online) 


\section{PENDAHULUAN}

Pada jaman era baru seperti sekarang ini teknologi komunikasi semakin berkembang setiap harinya. Salah satunya yaitu adanya media online. Media online berperan penting pada masyarakat untuk mendapatkan informasi. Selain media online, ada juga media cetak dan elektonik. Media online memiliki karakteristik seperi media massa lain, yaitu dapat menyediakan informasi dan berita-berita yang aktual. Berita yang ada pada media massa juga beragam seperti, permasalahan sosial, budaya, ekonomi, politik, gender, dan masih banyak lagi. Media massa juga dapat sebagai alat untuk menggiring opini masyarakat.

Media massa ialah suatu sarana komunikasi bagi masyarakat dalam menyampaikan pesan secara luas. Juga suatu media untuk massa yang memberikan informasi dengan istilah pers. Media massa juga memiliki visi misi dan ideologi tertentu yang dapat mempengaruhi kebijakan redaksional pada media tersebut (Januar, 2016:22 (Harnia et al., 2021, hal. 3146). Media massa memiliki cara yang berbeda-beda dalam menyusun dan mengelola berita. Agar berita yang akan disampaikan kepada masyarakat dapat dipahami. Karenanya, banyak dari masyarakat yang mempunyai pemahaman yang beragam tentang berita ini. Hal ini disebabkan karena asal mulanya masyarakat yang mendapatkan informasi tersebut.

Media online dapat diakses oleh masyarakat karena adanya jaringan internet. Menurut Bungin, 2006:136 (Indriyani et al., 2021, hal. 13) internet adalah bentuk konvergensi dari beberapa teknologi penting dahulu seperti komputer, televisi, radio, dan telepon. Media online mempunyai kelebihan dibandingkan dengan media lain. Media online juga memiliki cara penggunaan yang cukup praktis, yaitu hanya menggunakan gawai atau komputer yang dilengkapi jaringan internet. Media online juga sangat membantu masyarakat dalam melihat berita apa yang sedang disiarkan pada hari itu. Berita pada media online juga dapat diakses di mana dan kapan saja. Adapun media online yang menjadi subjek penelitian ini yaitu Kompas.com dan Sindonews.com.

M. Romli dan Asep Syamsul, 2012:34 (Lingga \& Syam, 2018) membagi pengertian media online menjadi dua, yaitu pengertian secara umum dan khusus. Pengertian media online secara umum, ialah segala jenis atau format media yang hanya dapat diakses melalui internet yang berisikan teks, foto, video, dan suara. Sedangkan media khusus adalah media yang dapat dimaknai sebagai sarana komunikasi online. Tentu dengan adanya media online ini banyak menimbulkan opini masyarakat yang beragam. Cara pandang masyarakat terhadap berita yang disampaikan oleh media pun juga berbeda. Tanggapan masyarakat juga berbeda-beda. Pada pemberitaan di media online Kompas.com dan Sindonews.com contohnya, selalu ada berita yang menarik untuk dikaji. Penelitian yang peneliti ambil yaitu mengenai pemberitaan tentang pengevakuasian 9 korban tanah longsong di Sulawesi Utara, yang diberitakan oleh media online Kompas.com dan Sindonews.com pada Selasa, 9 November 2021.

Menurut KBBI (V, 2016)berita ialah kabar atau keterangan mengenai kejadian atau peristiwa yang sedang hangat dibicarakan. Berita juga adalah suatu kejadian yang dapat di terbitkan di media massa. Berita memiliki banyak jenisnya. Pada penelitian ini termasuk ke dalam jenis berita bencana alam. Berita juga tidak hanyak sekedar cerita melainkan informasi yang dapat diterima oleh masyarakat.Berita mengenai bencana alam ini juga dapat menjadi acuan bahan pembelajaran dalam menulis berita di kelas VIII SMP.

Berita adalah laporan mengenai sebuah peristiwa yang terjadi di suatu tempat baik mengenai seorang tokoh ataupun yang lainnya yang dapat mempengaruhi pembaca untuk bersikap lebih baik lagi (Suryawati, 2011: 69 (Harnia et al., 2021, hal. 3147)). Sedangkan menurut Wirnani dan Rani (Aulia \& Anggraini, 2020, hal. 57) berita merupakan infomasi yang didapat oleh jurnalistik, lalu ditulis dalam media online untuk disampaikan kepada masyarakat mengenai peristiwa yang sedang terjadi.Jadi, berita dapat disimpulkan ialah tulisan tentang informasi yang disampaikan jurnalis yang dimuat di media online sehingga masyarakat dapat membacanya. 
838 Analisis Framing Berita Pengevakuasian Korban Tanah Longsor di Sulut pada Media Online

Sindonews. Com dan Kompas.Com - Thari Putri Kinanti Ishak, Hendra Setiawan

DOI : https://doi.org/10.31004/edukatif.v4i1.1908

Pada pemberitaan tersebut, tentunya banyak media yang meliput ke tempat kejadian. Pemberitaan tersebut juga menjadi buah bibir di masyarakat. Tentunya banyak faktor yang mengakibatkan terjadinya tanah longsor tersebut, apalagi bulan-bulan ini cuacanya sedang tidak bersahabat. Pergantian cuaca dari musim panas ke musim hujan juga membawa dampak negatif bagi masyarakat sekitar. Tetapi ada pula dampak positifnya. Dari kejadian ini dua media yaitu Kompas.com dan Sindonews.com juga ikut memberitakan kejadian tersebut. Penyampaian berita yang dibawakan cukup sederhana dan mudah dipahami masyarakat.

Di Indonesia bahkan di berbagai negara memang selalu ada bencana alam yang menimpa. Sejak tahun 2019 Indonesia sudah dikejutkan dengan datangnya virus Covid-19. Bahkan virus tersebut pun masih ada hingga sekarang. Bencana alam memang sering terjadi di mana dan kapan saja. Kali ini bencana alam terjadi di Sulawesi Utara yaitu Tanah Longsor. Masyarakat pun tentu tahu tanah longsor memang biasanya terjadi pada dataran tinggi. Karena itu masyarakat yang tinggal di dataran tinggi memang harus berhati-hati.

Media online Kompas.com adalah salah satu media yang banyak digemari dan terpercaya di Indonesia. Sejak tahun 2010 hingga 2019 Kompas.com juga sudah meneriman berbagai penghargaan dari masa ke masa. Kompas online pertama hadir pada 14 September 1995. Awalnya, Kompas Online atau KOL diakses dengan alamat Kompas.co.id dan hanya menampilkan replika dari berita-berita harian Kompas yang terbit hari itu. Bertujuan untuk memberikan layanan kepada masyarakat harian Kompas di tempat-tempat yang sulit dijangkau oleh jaringan. Hadirnya Kompas Online, para pembaca harian Kompas terutama di Indonesia bagian timur dan di luar negeri dapat menikmati harian Kompas pada hari itu, dan tidak harus menunggu hari esoknya.

SINDOnews merupakan salah satu portal berita besar dan berpengaruh yang memiliki gen Koran Sindo. Portal berita ini berdiri sejak 4 Juli 2012, di bawah managemen PT Sindonews Portal Indonesia (SPI). Sindonews memiliki tagline "Bukan Berita Biasa". Tagline ini menjadi kredo untuk membedakan Sindonews dengan portal-portal lain.Sindonews juga memberikan akses informasi akurat, berkualitas, dan cepat kepada masyarakat. Sindonews ini memiliki sinergi dengan media-media di MNC Group di berbagai platform seperti Televisi, Radio, dan Pay TV.

Menurut Pemikir Ilmu Komunikasi Alex Sobur, 2004 (Kurniawan \& Muktiyo, 2019, hal. 18) mengatakan framing ialah pendekatan untuk mengetahui bagaimana perspektif atau cara pandang yang digunakan wartawan dalam menyeleksi isu dan menulis berita.Framing pada berita merupakan cara media dalam mengemas sebuah berita dengan menonjolkan satu pesan yang ingin disampaikan supaya masyarakat tertuju pada satu pesan pada media tersebut. Menurut Eriyanto, 2018(Harnia et al., 2021, hal. 3147) mengatakan bahwa framing berkaitan dengan struktur dan proses kognitif, bagaimana seseorang mengolah sejumlah informasi dan ditunjukkan dalam skema tertentu. Framing juga berkaitan dengan penyusunan skema dalam mengolah sejumlah informasi yang akan disampaikan kepada masyarakat. Framing berfungsi untuk membuat berita agar memiliki kepentingan supaya diketahui oleh masyarakat (Kurniawan, 2019:19 (Harnia et al., 2021, hal. 3147)).

Analisis framing Zhongdan Pan dan Gerald M. Kosicki digunakan pada penelitian ini, karena merupakan model analisis framing yang mendetail dalam pembingkaian suatu berita. Analisis framing model ini berhubungan dengan makna. Analisis framing model Pan dan Kosicki berpendapat bahwa setiap berita mempunya frame yang berfungsi sebagai pusat organiasai ide. Ide yang dihubungkan dengan elemen yang berbeda dalam setiap teks berita, kutipan sumber, latar informasi, pemakaian kata atau kalimat tertentu ke dalam teks secara keseluruhan.

Pada penelitian mengenai berita pengevakuasian korban tanah longsor dalam media Kompas.com dan Sindonews.com. dari kedua media tersebut, terdapat beberapa perbadaan dan persamaan dalam penulisan beritanya. Dapat dilihat dari struktur sintaksis, skrip, tematik, dan retoris. Hal ini menjadi menjadi kewajaran apabila dalam setiap media memberitakan dan mengemas suatu berita dengan gayanya masing-masing. 
Perbedaan framing pada berita dapat terjadi karena tergantung bagaimana sudut pandang dari wartawan itu sendiri dalam mengemas suatu berita.

Maka, dalam melakukan penelitian ini pembaca dapat memahami dengan benar mengenai isi dari pemberitaan dengan jelas dan sesuai dengan realitas yang terjadi.framing dapat bermanfaat bagi masyarakat dan sekitarnya. Teori framing ini juga bermanfaat bagi siswa kelas VIII SMP, karena berkaitan dengan pembelajaran Bahasa Indonesia yaitu mengenai teks berita, apa itu teks berita, bagaimana cara mengidentifikasi unsur-unsur berita, pengertian berita, dan unsur-unsur berita $(5 \mathrm{~W}+1 \mathrm{H})$. Hal ini bersamaan dengan struktur skrip pada teori analisis framing dengan menganalisis unsur-unsur teks berita berupa $(5 \mathrm{~W}+1 \mathrm{H})$. Sehingga analisis framing ini dapat digunakan sebagai bahan ajar pada siswa SMP Kelas VIII dengan materi teks berita.

Pada penelitian sebelumnya membahas tentang analisis framing dan kaitannya dengan pembelajaran bahasa Indonesia adalah "Wacana Wanita dalam Majalah Kartini: Kajian Analisis Framing dan Kaitannya dengan Pembelajaran Bahasa Indonesia” ”ang ditulisolehInggaTriana. Hasil penelitian ini menunjukkan teks berita pembelajaran dari media Online yang dapat digunakan sebagai bahan ajar di sekolah dengan penyebaran informasi pada kalangan siswa SMP Kelas VIII.

Penelitian lainnya yaitu "Analisis Framing Berita Perundungan pada Media Online Detik.com dan Tribunnews.com sebagai Bahan Ajar Teks Berita si SMP” yang ditulis oleh Neng Tika Harnia, Ferina Meliasanti, dan Hendra Setiawan. Hasil penelitian ini memiliki sebuah perbedaan dan persamaan dalam melakukan framing terhadap pemberitaannya mengenai kasus perundungan. Pada aspek sintaksis media Detik.com menuliskan pemberitaan dengan menggunakan ketenangan dimana dalam setiap judul pemberitaannya di framing dengan menggunakan pilihan kata-kata perdamaian. Sedangkan pada Tribunnews.com dalam menuliskan judulnya bersifat menggeretak dengan terdapat penggunaan kata "viral" dan melibatkan.

Sedangkan peneliti menggunakan penelitian analisis framing berita pengevakuasian korban tanah longsor di Sulut pada media online Sindonews.Com dan Kompas.Com. pemberitaan ini juga dapat menjadi acuan bahan ajar bagi siswa SMP Kelas VIII dalam pembelajaran menulis teks berita. Selain itu juga untuk mengetahui bagaimana framing pada berita bekerja dalam membentuk suatu pemberitaan agar dapat memberitkan pemahaman menganai bagaimana cara memahami isi berita pada suatu media yang dikemas sebaik mungkin agar masyarakat tidak mendapatkan berita yang palsu atau hoak.

\section{METODE PENELITIAN}

Penelitian ini menggunakan pendekatan kualitatif, yang berarti prosedur penelitian yang menghasilkan data-data deskriptif yang berupa kata-kata tertulis maupun lisan dari orang-orang dan perilaku yang dapat diamati (Moleong, 2019:20 (Triadi \& Rokhmah, 2020, hal. 74)). Metode penelitian yang peneliti gunakan ialah metode analisis framing Zhongdan Pan dan Gerald M. Kosicki. Framing merupakan cara pandang atau perspektif yang digunakan oleh wartawan dalam menyeleksi isu dan menulis berita. Penelitian ini menggunakan metode penelitian analisis framing karena peneliti ingin melihat bagaimana media online Sindonews.com dan Kompas.Com untuk menyusun realitas mengenai Berita Pengevakuasian Para Korban Tanah Longsor di Sulut dalam bentuk berita yang akan disampaikan kepada masyarakat.

Teknik pengumpulan data dilakukan dengan, mengumpulkan informasi dari dua sumber yang berbeda dengan pemberitaan yang sama. Sumbernya berasal dari Kompas.com dan Sindonews.com. memperhatikan penggunaan bahasa yang digunakan dalam menulis berita. Lalu, ada teknik pengumpulan data yang peneliti lakukan ialah, menelaah satu berita dari dua sumber yaitu Kompas.com dan Sindonews.com. Kemudian menganalisis berita tersebut menggunakan framing Zhongdan Pan dan Kosicki. Mendeskripsikan hasil dari analisis tersebut dan membuat kesimpulan. 
Tabel 1 Data Berita yang akan diteliti

\begin{tabular}{cclll}
\hline \multirow{2}{*}{ No. } & \multicolumn{2}{c}{ Kompas.com } & \multicolumn{2}{c}{ Sindonews.com } \\
\cline { 2 - 5 } & \multicolumn{1}{c}{ Waktu Terbit } & \multicolumn{1}{c}{ Judul Berita } & Waktu Terbit & \multicolumn{1}{c}{ Judul Berita } \\
\hline \multirow{2}{*}{ 1. } & Selasa, 09 November & Detik-detik Tim SAR & Selasa, 09 & 9 Orang Penambang \\
& 2021 & Selamatkan 9 & November 2021 & Emas di Bolaang \\
& & & Mongondow Tertimbun \\
& & Penambang yang & Longsor. \\
& & Tertimbun Longsor 4 & \\
\hline
\end{tabular}

\section{HASIL DAN PEMBAHASAN PENELITIAN}

Analisis pada penelitian ini guna untuk mengetahui suatu framing dalam pemberitaan pada media Kompas.com dan Sindonews.com bekerja serta bagaimana pengimplementasiannya sebagai bahan ajar untuk teks berita pada siswa.

Analisis Pemberitaan Pengevakuasian Penambang Emas di Sulut yang Tertimbun Longsor pada media Kompas.com dan Sindonews.com

- Berita pada media Kompas.com: Detik-detik Tim SAR Selamatkan 9 Penambang yang Tertimbun Longsor 4 Jam di Sulut.

- Berita pada media Sindonews.com: 9 Orang Penambang Emas di Bolaang Mongondow Tertimbun Longsor.

Tabel 2 Hasil dan Pembahasan

\begin{tabular}{|c|c|c|}
\hline Struktur Framing & Kompas.com & Sindonews.com \\
\hline \multirow[t]{3}{*}{ Sintaksis } & $\begin{array}{l}\text { Struktur pada media online Kompas.com } \\
\text { yaitu menggunakan piramida terbalik, } \\
\text { dapat dilihat dari penggunaa lead pada } \\
\text { berita yang memaparkan mengenai } \\
\text { pengevakuasian } 9 \text { orang penambang } \\
\text { emas yang tertimbun longsor selama } 4 \\
\text { jam di Sulut. }\end{array}$ & $\begin{array}{l}\text { Struktur pada media online } \\
\text { Sindonews.com, menggunakan piramida } \\
\text { terbalik, dapat dilihat dari penggunaan } \\
\text { lead yang dipakai pada berita mengenai } \\
9 \text { orang penambang emas di Bolaang } \\
\text { Mongondow tertimbun longsor. }\end{array}$ \\
\hline & $\begin{array}{l}\text { Penulisan berita ini terdapat informasi } \\
\text { atau sumber yang dijadikan sebagai } \\
\text { penulisan teks berita. Sumber tersebut } \\
\text { berasal dari Humas Badan SAR Nasional } \\
\text { (Basarnas) Manado Feri Ariyanto yang } \\
\text { berada di lokasi kejadian. }\end{array}$ & $\begin{array}{l}\text { Pada teks berita ini terdapat satu kutipan } \\
\text { yang disampaikan oleh jurnalis Abdul } \\
\text { Muin. Namun, secara keseluruhan dalam } \\
\text { penulisan berita jurnalis tidak } \\
\text { memasukan opininya mengenai kasus } 9 \\
\text { orang penambang emas ini. }\end{array}$ \\
\hline & $\begin{array}{l}\text { Setelah dievakuasi } 9 \text { penambang tersebut } \\
\text { segera dilarikan ke Puskesmas Dumoga. } \\
\text { Dari keterangan warga setempat, para } \\
\text { korban tambang yang tertimbun longsor } \\
\text { memiliki kedalaman sekitar 50-100 } \\
\text { meter. }\end{array}$ & $\begin{array}{l}\text { Penutup pada berita ini yaitu belum } \\
\text { diketahui nasib dari kesembilan } \\
\text { penambang emas tersebut. Nampak dari } \\
\text { video yang beredar di sosial media, } \\
\text { beberapa orang penambang lainnya } \\
\text { sedang berusaha menyelamatkan } \\
\text { kesembilan penambang yang tertimbun } \\
\text { longsor tersebut. }\end{array}$ \\
\hline
\end{tabular}




\begin{tabular}{|c|c|c|}
\hline & $\begin{array}{l}\text { Pada bagian awal berita terdapat gambar } \\
\text { menganai bagaimana cara Tim SAR } \\
\text { dalam proses pengevakuasian korban. }\end{array}$ & \\
\hline & $\begin{array}{l}\text { Pada bagian penutupnya terdapat kutipan } \\
\text { bahwa untuk mencegah kejadian tersebut } \\
\text { terulang, pihaknya mengusulkan untuk } \\
\text { menutup tambang emas. }\end{array}$ & \\
\hline Skrip $(5 \mathrm{~W}+1 \mathrm{H})$ & $\begin{array}{l}\text { Pada bagian skrip } 5 \mathrm{~W}+1 \mathrm{H} \text { dalam berita } \\
\text { Kompas.com tentang pengevakuasian } \\
\text { korban longsor di Sulawesi Utara ini } \\
\text { dapat dikatakan bahwa unsur } 5 \mathrm{~W}+1 \mathrm{H} \\
\text { sudah ada dalam keseluruhan isi teks } \\
\text { berita. Tetapi untuk How tidak terlalu } \\
\text { dijelaskan secara spesifik. }\end{array}$ & $\begin{array}{l}\text { Dalam skrip } 5 \mathrm{~W}+1 \mathrm{H} \text { pada } \text { berita } \\
\text { Sindonews.com mengenai } 9 \text { orang } \\
\text { penambang emas yang tertimbun } \\
\text { longsor di Bolaang Mongondow. } \\
\text { Dikatakan bahwa unsur } 5 \mathrm{~W}+1 \mathrm{H} \text { sudah } \\
\text { ada pada keseluruhan isi teks berita. } \\
\text { Namun untuk How tidak dijelaskan. }\end{array}$ \\
\hline Tematik & $\begin{array}{l}\text { Pemberitaan mengenai teks tersebut } \\
\text { berisi } 11 \text { paragraf singkat, serta beberapa } \\
\text { kutipan langsung dalam pernyataan dari } \\
\text { sumber untuk mendukung teks. Tema } \\
\text { yang ditekankan dalam berita ini, ialah } \\
\text { mengapa terjadinya longsor pada } \\
\text { penambangan emas. }\end{array}$ & $\begin{array}{l}\text { Pada pemberitaan ini terdapat } 5 \text { paragraf } \\
\text { yang ditulis dengan jelas sehingga } \\
\text { berkelanjutan antara kalimat satu dengan } \\
\text { yang lainnya. }\end{array}$ \\
\hline \multirow[t]{2}{*}{ Retoris } & $\begin{array}{l}\text { Kompas.com banyak menggunkaan } \\
\text { kutipan pernyataan dari sumber untuk } \\
\text { memperkuat argumentasi dari berita } \\
\text { tersebut. Namun, untuk pemilihan dan } \\
\text { penggunaan kalimat pada teks berita ini } \\
\text { mudah dipahami oleh pembaca. Bahasa } \\
\text { yang digunakanpun sederhana dan tidak } \\
\text { membuat kesan rancu. }\end{array}$ & $\begin{array}{l}\text { Pada media Sindonews.com hanya } \\
\text { terdapat satu kutipan pernyataan dari } \\
\text { sumber. Tetapi dalam pemilihan kata } \\
\text { yang digunakan pada teks berita cukup } \\
\text { jelas dan dapat dipahami. Sehingga } \\
\text { masyarakat yang membacanyapun tidak } \\
\text { kebingungan. }\end{array}$ \\
\hline & $\begin{array}{l}\text { Terdapat kata "pengevakuasian" pada isi } \\
\text { dan judul berita yang di mana berarti } \\
\text { pertolongan yang dilakukan oleh } \\
\text { masyarakat atau Tim SAR yang biasa } \\
\text { menolong korban kecelakaan. Juga } \\
\text { terdapat penggunaan kata "korban" pada } \\
\text { isi berita yang memiliki arti orang yang } \\
\text { sedang mengalami atau sedang terkena } \\
\text { musibah. }\end{array}$ & $\begin{array}{l}\text { Terdapat penggunaan kata "tertimbun" } \\
\text { pada isi berita yang memiliki arti sebuah } \\
\text { bencana alam seperti tanah longsor yang } \\
\text { dapat terjadi oleh siapa saja dan dapat } \\
\text { menyebabkan seseorang luka-luka } \\
\text { bahkan meninggal dunia. }\end{array}$ \\
\hline
\end{tabular}

Hasil analisis framing Zhongdan Pan dan Kosicki tentang berita pengevakuasian korban tanah longsor pada media Kompas.com dan Sindonews.com juga dapat digunakan sebagai bahan ajar pada pembelajaran materi teks berita di Kelas VIII SMP. Pada pembelajaran tels berita, framing berfungsi untuk mengetahui unsur-unsur ada teks berita juga dapat digunakan sebagai pengetahuan guna memahami isi dari suatu berita agar tidak termakan berita hoaks. 
842 Analisis Framing Berita Pengevakuasian Korban Tanah Longsor di Sulut pada Media Online

Sindonews. Com dan Kompas.Com - Thari Putri Kinanti Ishak, Hendra Setiawan

DOI : https://doi.org/10.31004/edukatif.v4i1.1908

\section{KESIMPULAN}

Berdasarkan pembahasan berikut, dapat disimpulkan bahwa Kompas.com dan Sindonews.com dalam memberitakan suatu peristiwa menggunakan teknik piramida terbalik. Berisi sumber dari kutipan narasumber, isi dari teks berita yang tidak terlalu panjang namun sudah memuat fakta yang ingin disampaikan. Namun, Kompas.com dan Sindonews.com tentu memiliki perbedaan dan persamaan dalam menyampaikan berita. Kompas.com banyak menggunakan kutipan dari narasumber, sedangkan Sindonews.com tidak terlalu banyak menggunakan kutipan dari narasumber. Berita yang ditulis menggunakan kalimat sederhana, sehingga mudah dipahami ole masyarakat. Lalu, menentukan tema dengan mengangkat masalah yang dibutuhkan pembaca. Terdapat unsur $5 \mathrm{~W}+1 \mathrm{H}$, sehingga serangkaian berita dapat dipahami dengan baik oleh pembaca. Berita mengenai bencana alam ini juga dapat menjadi acuan bahan pembelajaran dalam menulis berita di kelas VIII SMP.

\section{UCAPAN TERIMA KASIH}

Saya panjatkan puji dan syukur atas rahmat dan karunia Allah SWT, kepada kedua orang tua yang senantiasa memberikan doa dan dukungannya, kepada dosen pembimbing, dan kepada teman-teman serta semua pihak yang telah membantu saya dalam menyelesaikan penelitian ini.

\section{DAFTAR PUSTAKA}

Annapisa, M. (2018). Peran Media Cetak Lokal Dalam Komunikasi Bencana Sebagai Pendukung Manajemen Bencana. Buletin Pembangunan Berkelanjutan, 2(1), 102-115. Https://Journal.Uir.Ac.Id/Index.Php/Buletinpembangunan/Article/View/3856

Anwar, Y., Rozaq, A., Lathifah, E. A., Putra, R. A., Purnamasari, W. S., Suherman, Y., \& Sunarti, Y. (2021). Dampak Covid-19 Terhadap Pengawasan Orang Tua Dalam Pembelajaran Jarak Jauh Siswa Sd Negeri 004 Palaran. Jurnal Swarnabhumi, 6(1), 22-31. Https://Jurnal.UnivpgriPalembang.Ac.Id/Index.Php/Swarna/Article/View/5077

Apsari, T. A. (2018). Bingkai Berita Bencana Lumpur Lapindo Di Media Online. Jurnal Komunikasi Dan Kajian Media, 2(1), 1-17. Https://Jurnal.Untidar.Ac.Id/Index.Php/Komunikasi/Article/View/756

Aulia, N., \& Anggraini, N. (2020). Analisis Kesalahan Morfologi Dalam Artikel Pendidikan Surat Kabar Di Era New Normal 2020. Jurnal Sasindo Unpam, 8(2), 56-69.

Harnia, N. T., Meliasanti, F., \& Setiawan, H. (2021). Analisis Framing Berita Perundungan Pada Media Online Detik.Com Dan Tribunnews.Com Sebagai Bahan Ajar Teks Berita Di Smp. Edukatif: Jurnal Ilmu Pendidikan, 3(5), 3145-3153. Https://Doi.Org/Https://Doi.Org/10.31004/Edukatif.V3i5.1240

Indriyani, M., Bambang, A. ., \& Hapsari, D. T. (2021). Efektivitas Penggunaan Media Online Tirto.Id Terhadap Pemenuhan Kebutuhan Informasi Berita Livi Zheng. Komunika: Jurnal Ilmu Komunikasi, 8(1), 12-18. Https://Doi.Org/10.22236/Komunika.V8i1.5714

Kandiawan, B. A., \& Nugroho, C. (2018). Analisis Framing Zhongdang Pan Dan Kosicki Berita Insiden Piala Presiden 2018 Pada Media Dalam Jaringan Kompas.Com Dan Tempo.Co Edisi Februari 2018. EProceeding Of Management, 5(3), 4021-4027.

Kurniawan, D., \& Muktiyo, W. (2019). Framing Berita Presiden Donald Trump Oleh Media Asing Dan Media Nasional. Intelektiva: Jurnal Ekonomi, Sosial \& Humaniora, 01(03), 17-23.

Lingga, M. A., \& Syam, H. M. (2018). Analisis Framing Pemberitaan Lesbian, Gay, Biseksual Dan Transgender (Lgbt) Pada Media Online Republika.Co.Id Dan Tempo.Co. Jurnal Ilmiah Mahasiswa Fisip Unsyiah, 3(1). 
843 Analisis Framing Berita Pengevakuasian Korban Tanah Longsor di Sulut pada Media Online Sindonews. Com dan Kompas.Com - Thari Putri Kinanti Ishak, Hendra Setiawan

DOI : https://doi.org/10.31004/edukatif.v4i1.1908

Nugroho, W. (2008). About Kompas.Com. Kompas.Com. Https://Inside.Kompas.Com/About-Us. Diakses Pada 24 Desember 2021.

Rafiq, F. (2014). Pembingkaian Berita Bencana Alam Di Harian Fajar Edisi Bulan Januari-Februari 2014 (Analisis Framing) [Uin Alauddin Makassar]. Http://Repositori.Uin-Alauddin.Ac.Id/10840/

Safitri, I., Firman, \& Neviyarni. (2019). Pengaruh Bahan Ajar Tematik Terpadu Terhadap Pencegahan Bullying Di Sekolah Dasar. Edukatif: Jurnal Ilmu Pendidikan, 1(3), 244-249. Https://Doi.Org/10.31004/Edukatif.V3i5.1084

Setiawan, H., \& Nulhakim, L. (2019). Analisis Framing Zong Dang Pan Dan Gerald M. Kosicki Pada Pemberitaan Kasus Dugaan Ujaran Kebencian Habib Bahar Bin Smith Kepada Presiden Joko Widodo (Studi Kasus Pada Kompas.Com Edisi 3 Desember 2018). Jurnal Artikula, 2(1), 48-53. Https://Doi.Org/10.30653/006.201921.19

Simatupang, R. (2021). Analisis Framing Pemberitaan Kompas.Com Tentang Covid-19 Di Dki Jakarta. Jurnal Pustaka Komunikasi, 4(1), 39-52. Https://Doi.Org/10.32509/Pustakom.V4i1.1315

Solihat, M., Setiawan, H., \& Meliasanti, F. (2021). Kajian Morfologis Pada Pemberitaan Habib Rizieq Shihab Rekomendasinya Sebagai Materi Menyusun Teks Berita Di Smp. Edukatif: Jurnal Ilmu Pendidikan, 3(6), 3828-3838. Https://Doi.Org/Https://Doi.Org/10.31004/Edukatif.V3i6.1259

Suprobo, T., Siahainenia, R., \& Sari, D. K. (2016). Analisis Framing Media Online Dalam Pemberitaan Profil Dan Kebijakan Menteri Susi Pudjiastuti (Studi Pada Situs Berita Detik.Com, Kompas.Com Dan Antaranews.Com Periode Oktober - Desember 2014). Cakrawala Jurnal Penelitian Sosial, 5(1), 119138. Http://Ejournal.Uksw.Edu/Cakrawala/Article/View/499

Tanoesoedibjo, H. (2012). Tentang Kami (Sindonews.Com). Sindonews.Com. Https://Index.Sindonews.Com/About/. Diakses Pada 24 Desember 2021.

Triadi, R. B., \& Rokhmah, D. A. (2020). Pemerolehan Bahasa Pada Anak Usia Dini 3 Dan 4 Tahun Di Bimba Aiueo Permata Pamulang. Jurnal Sasindo Unpam, 8(2), 70-78. Http://Www.Tjyybjb.Ac.Cn/Cn/Article/Downloadarticlefile.Do?Attachtype=Pdf\&Id=9987

Triana, I. (2014). Wacana Wanita Dalam Majalah Kartini: Kajian Analisis Framing Dan Kaitannya Dengan Pembelajaran Bahasa Indonesia [Universitas Mataram]. In Universitas Mataram Repository. Http://Eprints.Unram.Ac.Id/Id/Eprint/9401

V, K. E. (2016). Berita. Kamus Besar Bahasa Indonesia Daring. Https://Kbbi.Kemdikbud.Go.Id/Entri/Berita. Diakses Pada 24 Desember 2021. 